\title{
PENINGKATAN PERENCANAAN ASUHAN KEPERAWATAN KOMUNITAS DI RUMAH SAKIT
}

\author{
Erta Iman Jelita Harefa/181101138 \\ $\underline{\text { ertahrf08@gmail.com }}$
}

\begin{abstract}
Abstrak
Latar belakang: Berdasarkan World Health Organization (WHO) tahun 2009 mengatakan bahwa $60-80 \%$ pelayanan kesehatan di dunia diberikan oleh perawat sedangkan di Afrika hampir 85\% pelayanan kesehatan diberikan oleh perawat. Sehingga pemahaman dan kemampuan untuk mengaplikasikan keperawatan kesehatan komunitas menjadi suatu hal yang sangat dibutuhkan.

Tujuan: Penulisan ini bertujuan untuk mengetahui dan memberi informasi tentang peningkatan perencanaan asuhan keperawatan komunitas di rumah sakit.

Metode: Penulisan ini menggunakan metode literature review dengan pendekatan jurnal atau artikel, buku dan $e$-book yang relevan dan akurat serta berfokus peningkatan perencanaan asuhan keperawatan komunitas di rumah sakit. Adapun jurnal atau artikel dan $e$-book yang digunakan pada literature review adalah jurnal atau artikel dan e-book yang didapatkan dengan menggunakan Google Scholar, Portal Garuda, dan Jurnal Keperawatan Indonesia.

Hasil: Berdasarkan hasil pencarian literatur di dapatkan langkah dalam menyusun perencanaan asuhan keperawatan komunitas yang terdiri dari: menetapkan prioritas, menetapkan sasaran, menetapkan tujuan, dan menetapkan rencana.

Pembahasan: Dalam peningkatan Perencanaan asuhan keperawatan komunitas dapat dilakukan dengan cara sebagai berikut: 1) Melakukan pendidikan kesehatan tentang penyakit, 2) Melakukan demonstrasi keterampilan cara menangani penyakit, 3) Melakukan deteksi dini tanda-tanda gangguan penyakit, 4) Melakukan kerja sama dengan ahli gizi dalam menentukan diet yang tepat. Penutup: Dari hasil dan pembahasan yang telah diuraikan diatas bahwa peningkatan perencanaan asuhan keperawatan komunitas di rumah sakit sudah ada kemajuan dengan adanya perawat yang khusus dibidang komunitas.
\end{abstract}

Kata kunci: perencanaan, asuhan keperawatan, komunitas 


\section{LATAR BELAKANG}

Keperawatan kesehatan komunitas merupakan salah satu bidang yang sangat strategis dan berperan aktif dalam meningkatkan status kesehatan masyarakat. Namun kebenarannya atau faktanya perawat kesehatan komunitas yang ada di Indonesia khususnya yang ada di puskesmas tidak banyak melaksanakan tugas profesi tersebut dengan berbagai macam alasan dan permasalahan (Swarjana, 2016).

Komunitas merupakan kelompok sosial yang tinggal dalam suatu tempat yang saling berinteraksi atau berkomunikasi antar satu sama lain. Komunitas adalah kelompok masyarakat yang tinggal di suatu lokasi atau tempat yang sama dengan pemerintahan yang sama.

Berdasarkan World Health Organization (WHO) tahun 2009 mengatakan bahwa $60-80 \%$ pelayanan kesehatan di dunia diberikan oleh perawat sedangkan di Afrika hampir $85 \%$ pelayanan kesehatan diberikan oleh perawat. Sehingga pemahaman dan kemampuan untuk mengaplikasikan keperawatan kesehatan komunitas menjadi suatu hal yang sangat dibutuhkan.

Hal yang penting dalam keperawatan kesehatan komunitas adalah pemberian asuhan keperawatan (askep) komunitas secara langsung sesuai dengan kebutuhan komunitas masing-masing. Asuhan keperawatan komunitas merupakan inti dari segala tindakan keperawatan dan praktek keperawatan dan juga aplikasi dari berbagai tindakan dan kerangka kerja dari referensi, konsep dan teori keperawatan komunitas.

Hal yang utama dari proses asuhan keperawatan komunitas yaitu untuk meningkatkan derajat kesehatan masyarakat secara optimal. Proses keperawatan komunitas merupakan metode asuhan keperawatan yang bersifat alamiah, sistematis, dinamis, kontinu dan secara berkesinambungan untuk memecahkan masalah kesehatan pasien/klien, keluarga, kelompok dan masyarakat.

Kesehatan yang optimal dalam keperawatan komunitas lebih menekankan pada upaya peningkatan kesehatan dan pencegahan terhadap berbagai gangguan kesehatan dan keperawatan dalam upaya-upaya pengobatan dan perawatan serta pemulihan bagi yang sedang menderita penyakit maupun dalam kondisi pemulihan terhadap penyakit.

Keperawatan komunitas ditujukan untuk mempertahankan dan meningkatkan kesehatan serta memberikan bantuan 
melalui intervensi keperawatan sebagai dasar dalam mengatasi berbagai masalah keperawatan kesehatan yang dihadapi dalam kehidupan sehari-hari.

\section{TUJUAN}

Tujuan penulisan ini adalah untuk mengetahui dan memberi informasi tentang peningkatan perencanaan asuhan keperawatan komunitas di rumah sakit.

\section{METODE}

Penulisan ini menggunakan metode literature review dengan pendekatan jurnal atau artikel, buku dan e-book yang relevan dan akurat serta berfokus pada peningkatan perencanaan asuhan keperawatan komunitas di rumah sakit. Adapun jurnal atau artikel dan e-book yang digunakan pada literature review adalah jurnal atau artikel dan e-book yang didapatkan dengan menggunakan Google Scholar, Portal Garuda, dan Jurnal Keperawatan Indonesia.

\section{HASIL}

Berdasarkan hasil pencarian literatur di dapatkan langkah dalam menyusun perencanaan asuhan keperawatan komunitas sebagai berikut:
1. Menetapkan Prioritas

Menetapkan prioritas masalah ini di perlukan keterlibatan masyarakat dalam pertemuan musyawarah masyarakat. Sehingga para perawat kesehatan komunitas dapat membimbing atau mengarahkan masyarakat dalam mengutamakan atau memprioritaskan masalah yang ada. Adapun kriteria yang harus diperhatikan oleh perawat dalam menentukan prioritas masalah yang terdiri dari: mengetahui kesadaran masyarakat akan masalah, motivasi masyarakat untuk menyelesaikan masyarakat, kemampuan perawat dalam mempengaruhi penyelesaian masalah, ketersediaan pihak lain terhadap solusi masalah, mengetahui konsekuensi jika masalah tidak terselesaikan dan mempercepat penyelesaian masalah dengan kecepatan yang dapat dicapai.

2. Menetapkan Sasaran

Setelah melakukan penetapan prioritas masalah kesehatan selanjutnya menetapkan sasaran. Sasaran merupakan hasil yang diharapkan. Dalam pelayanan kesehatan sasaran merupakan pernyataan situasi kedepan, kondisi atau status jangka panjang dan belum bisa diukur. 
3. Menetapkan Tujuan

Tujuan adalah pernyataan hasil yang diharapkan dan dapat diukur, dibatasi waktu berorientasi pada kegiatan. Karakteristik dalam penulisan tujuan yaitu menggunakan kata kerja, menggambarkan tingkah laku akhir, kualitas dan kuantitas penampilan, dan cara mengukur penampilan.

4. Menetapkan Rencana Intervensi Adapun yang harus diperhatikan dalam menetapkan intervensi keperawatan kesehatan komunitas yaitu hal yang akan dilaksanakan, waktu pelaksanaan, jumlah, target, dan lokasi. Saat melakukan penetapan rencana intervensi keperawatan maka perlu diperhatikan tentang program pemerintah terkait dengan masalah kesehatan yang ada, kondisi atau situasi, sumber daya yang ada baik didalam maupun diluar komunitas yang dapat dimanfaatkan, program yang sudah dijalankan, dan mengedepankan upaya promotif dan preventif tanpa mengabaikan kuratif dan rehabilitatif.

\section{PEMBAHASAN}

Perencanaan keperawatan merupakan penyusunan rencana tindakan keperawatan yang akan dilaksanakan untuk mengatasi masalah sesuai dengan diagnosa keperawatan yang sudah ditentukan dengan tujuan terpenuhinya kebutuhan pasien. Dalam peningkatan Perencanaan asuhan keperawatan komunitas dapat dilakukan dengan cara sebagai berikut: 1) Melakukan pendidikan kesehatan tentang penyakit, 2) Melakukan demonstrasi keterampilan cara menangani penyakit, 3) Melakukan deteksi dini tanda-tanda gangguan penyakit, 4) Melakukan kerja sama dengan ahli gizi dalam menentukan diet yang tepat, 5) Melakukan olahraga secara rutin, 6) Melakukan kerja sama dengan pemerintah atau aparat setempat untuk memperbaiki lingkungan komunitas, 7) Melakukan rujukan ke rumah sakit bila diperlukan.

Dalam hal ini keperawatan kesehatan komunitas merupakan praktik promotif dan proteksi kesehatan populasi yang menggunakan pengetahuan atau ilmu keperawatan, sosial, dan ilmu kesehatan masyarakat. Menurut American Public Health Association (2004) Keperawatan kesehatan komunitas merupakan sintesis dari ilmu kesehatan masyarakat dan teori keperawatan profesional yang bertujuan meningkatkan derajat kesehatan pada keseluruhan komunitas.

Menurut Istitute of Medicine (IOM) tahun 2003 mendefenisikan keperawatan 
kesehatan komunitas sebagai layanan keperawatan profesional yang diberikan perawat oleh perawat yang telah memperoleh pendidikan keperawatan komunitas atau displin lain yang berkaitan dan bekerja untuk meningkatkan derajat kesehatan yang berfokus pada masyarakat.

\section{PENUTUP}

Dari hasil dan pembahasan yang telah diuraikan diatas bahwa peningkatan perencanaan asuhan keperawatan komunitas di rumah sakit sudah ada kemajuan dengan adanya perawat yang khusus dibidang komunitas. Untuk memberikan asuhan keperawatan komunitas yang lebih maju maka diperlukan dukungan perawat, pihak rumah sakit, dan pemerintah untuk dapat mengoptimalkan pelayanan kesehatan.

\section{REFERENSI}

Achjar, Komang A. H. (2011). Teori dan

Praktek Asuhan Keperawatan Komunitas. Jakarta: EGC.

Andarmoyo, S. (2012). Keperawatan Keluarga: Konsep Teori, Proses, dan Praktik Keperawatan. Yogyakarta: Graha Ilmu.
Anderson, Elizabeth T., Mcfarlane, J. (2006). Buku Ajar Keperawatan Komunitas Teori dan Praktik. Jakarta: EGC.

Andini, Nur A. (2018). Gambaran Faktor Yang Mempengaruhi Pelaksanaan Asuhan Keperawatan Komunitas di Puskesmas Kota Makassar, Jurnal FIK, 10-28.

Efendi, Ferry \& Makhfud. (2009). Keperawatan Kesehatan Komunitas Teori dan Praktik Dalam Keperawatan. Jakarta: Salemba Medika.

Friedman, M. (2010). Buku Ajar Keperawatan Keluarga Riset, Teori, dan Praktek. Jakarta: EGC.

Harnilawati. (2013). Pengantar Ilmu Keperawatan Komunitas. Sulawesi: Pustaka As Salam.

Hidayat, A. Aziz Alimul. (2008). Pengantar Konsep Dasar Keperawatan. Jakarta: Salemba Medika.

Jaji. (2012). Peran Keperawatan Komunitas Dalam Peningkatan Derajat Kesehatan Masyarakat 
Menuju MDGs 2015, Jurnal FKIK, 3-11.

Mubarak, W. I. (2005). Pengantar Keperawatan Komunitas. Jakarta: Sagung Seto.

Mubarak, W., I \& Chayatin, N. (2009). Ilmu Keperawatan Komunitas Pengantar dan Teori. Jakarta: Salemba Medika.

Simamora, R. H. (2008). Peran Manajer Dalam Pembinaan Etika Perawat Pelaksana Dalam Peningkatan Kualitas Pelayanan Asuhan Keperawatan. Jurnal IKESMA.

Simamora, R. H. (2009). Dokumentasi Proses Keperawatan. Jember University Press.

Simamora, R. H. (2010). Komunikasi Dalam Keperawatan. Jember University Press.

Utama, H., Suri, M. Nur, dkk. (2013). Asuhan Keperawatan Komunitas Pada Kelompok Kusta di Wilayah Puskesmas Sidotopo Surabaya, Jurnal FIK, 23-26.

Widagdo, Wahyu. (2016). Keperawatan Keluarga dan Komunitas. Jakarta: Pusdik SDM Kesehatan.
Widyanto, Faisalado C. (2014).

Keperawatan

Komunitas

Dengan Pendekatan Praktis. Yogyakarta: Nuha Medika. 